\title{
Diel grazing patterns of all ontogenetic stages of Euphausia lucens and in situ predation rates on copepods in the southern Benguela upwelling region
}

\author{
V. Stuart ${ }^{1}$, S. C. Pillar ${ }^{2}$ \\ ${ }^{1}$ Marine Biology Research Institute, Department of Zoology, University of Cape Town, Rondebosch 7700, South Africa \\ ${ }^{2}$ Sea Fisheries Research Institute, Private Bag X2, Rogge Bay, Cape Town 8012, South Africa
}

\begin{abstract}
Diel feeding rhythms of all developmental stages of Euphausia lucens were investigated using the gut fluorescence technique. Pronounced nocturnal increases in gut pigment levels were noted in adults and juveniles, but no diel changes were recorded for the calyptopis larvae. Furcilia larvae showed diel feeding rhythms in 2 out of 3 cruises. Feeding periodicity was thus related to ontogenetic stage, which in turn was linked to vertical migratory behaviour. Adults and juveniles undergo extensive daily migrations while larval stages are largely confined to the upper layers. Gut pigment levels in adults and juveniles were influenced by ambient chlorophyll levels, being ca 10-fold higher under favourable conditions. Carnivorous feeding on copepods was examined by counting the number of copepod mandible pairs in euphausiid stomachs. Carnivory predominated in adults, with juveniles consuming relatively few copepods and larval stages being primarily herbivorous. The size of copepods consumed by adult euphausiids was estimated from the relationship between mandible width and copepod prosome length. Copepods in the size range 0.15 to $2.19 \mathrm{~mm}$ prosome length were consumed (mean: 0.54 to $0.86 \mathrm{~mm}$ ). There was little relationship between euphausiid length and length of copepod consumed, although larger euphausiids contained more copepod mandibles than smaller ones (up to 8 pairs per stomach). Camivory occurred predominantly during the day, except under conditions of low phytoplankton concentrations, when large numbers of copepods were eaten at night. A significant inverse relationship was found between gut pigment levels at night and the number of copepod mandibles per stomach, suggesting that phytoplankton concentration may be the trigger causing a switch in diet from one food source to the next. Carbon-specific ingestion rates on phytoplankton and copepod prey indicate that E. lucens is a true omnivore, with between 15 and $60 \%$ of total carbon ingested being in the form of plant material and the remainder being obtained from copepod prey. Carnivory was of prime importance when chlorophyll levels were low, but even during high phytoplankton concentrations, still contributed up to $40 \%$ of total carbon ingested. E. lucens is thus well adapted to cope with the fluctuating food environment characteristic of upwelling areas. Population ingestion rates indicate that grazing by $E$. lucens has a negligible impact on phytoplankton stocks in the southern Benguela region. However, predation on copepods is of greater significance and may act to limit secondary production in this area
\end{abstract}

\section{INTRODUCTION}

Grazing by zooplankton organisms has received considerable attention in the past few decades, with numerous studies examining variables such as phytoplankton concentration and composition, cell size, food quality and developmental stage of the feeder (Paffenhöfer 1988). In the southern Benguela upwelling region zooplankton organisms are exposed to a rich, but highly variable and unpredictable food sup- ply. Newly upwelled waters are characterised by high nutrient levels with extremely low chlorophyll concentrations (Brown 1984), succeeded by dense phytoplankton blooms lasting for a few days or weeks (Brown \& Hutchings 1987). This results in tongues of highly productive water which are extremely variable in their extent and distribution along the west coast of southern Africa. Local zooplankton species must, therefore, have evolved feeding strategies to cope with such unstable conditions. Considering the behavioural 
complexities of zooplankton feeding, with numerous factors influencing ingestion rates, it is apparent that in situ measurements need to be obtained to examine how this prolific, but unpredictable, food supply is exploited. The gut fluorescence technique has been increasingly used to measure herbivorous feeding rates in copepods (Mackas \& Bohrer 1976, Dagg \& Wyman 1983, Wang \& Conover 1986, Dagg \& Walser 1987. Peterson et al. 1990) as well as euphausiids (Willason \& Cox 1987). This technique has provided a rapid and simple method for measuring in situ grazing rates of small herbivorous organisms.

One of the dominant zooplankton organisms in the southern Benguela region is the euphausiid Euphausia lucens, which also forms a major part of the diet of many of the commercially important fish species such as anchovy and juvenile hake (James 1987, Payne et al. 1987). Laboratory grazing experiments have established that adult $E$. lucens filter natural phytoplankton assemblages at an overall grazing rate of 1 to $3 \mathrm{ml}(\mathrm{mg}$ dry $w t)^{-1} h^{-1}$, with larger cells, particularly dinoflagellates, being filtered at a significantly greater rate than other cells (Stuart 1989). However, it is not known how these values compare to grazing rates in the natural environment, or whether E. Iucens exhibits any form of diel feeding rhythms.

Studies on the relationship between vertical migration and diel feeding activity in several species of euphausiids have shown that strongly migrating species exhibit pronounced diel feeding rhythms, while non-migrating species show little obvious diel change in feeding activity ( $\mathrm{Hu}$ 1978). Thus it is of interest to examine whether the same holds true for different developmental stages of the same species, since adult and juvenile Euphausia lucens undergo daily vertical migrations from the bottom (ca $200 \mathrm{~m}$ ) where they occur during the day, to the surface layers at night, while calyptopis and furcilia larval stages remain in the upper layers of the water column throughout the day and night (Pillar et al. 1989). Little is known about the feeding rates of the larval stages of euphausiids or whether they exhibit diel feeding rhythms.

Euphausia Iucens, like most other euphausid species, can also feed carnivorously, and laboratory studies have shown them to be capable of consuming Artemia nauplii, copepods and anchovy larvae (Pillar 1984a, Stuart 1986). This behaviour may represent an alternative feeding mechanism to which euphausiids might switch when suitable prey are abundant or when phytoplankton densities are low, such as in newly upwelled waters or during the decline of a phytoplankton bloom. Few quantitative comparisons of herbivorous and carnivorous feeding by euphausiids on natural food items are available (Ohman 1984, McClatchie 1985, Price et al. 1988) and the extent of carnivorous feeding in the field and its relative contribution to the daily food intake remains unquantified. Also, the factors causing a switch from one food source to the other still require investigation, as well as the predatory impact of euphausiids on mesozooplankton populations and food chain dynamics. Considering the constantly fluctuating physical environment of the southern Benguela upwelling region, with rapid changes in phytoplankton species composition, size distributions and concentrations during different phases of upwelling (Pitcher et al. in press), it would be advantageous for zooplankton organisms to be able to switch their diet between herbivorous and carnivorous feeding in order to exploit a wide range of food items.

In this study camivorous feeding by Euphausia lucens was investigated through analysis of gut contents, which, under certain trophic conditions, revealed large quantities of copepod remains. Copepod mandibles are particularly resistant to digestion, being composed of silica and chitin (Sullivan et al. 1975), and can be used as an indication of the number and size of copepods consumed. Enumeration of mandibles, combined with the analysis of gut pigments, was used in this paper to assess the relative roles of herbivory and carnivory in E. lucens as well as diel variations in the feeding rates.

\section{MATERIALS AND METHODS}

Collection of samples. Feeding rhythms in Euphausia lucens were examined during 3 cruises (1 January, 11 January and 19 April 1989) off the west coast of South Africa (Fig. 1). These cruises will subsequently be referred to as Cruises 1 to 3 respectively. Sampling locations ranged between the inner shelf $(100 \mathrm{~m})$ to the outer shelf and slope (200 to $450 \mathrm{~m}$ ). Euphausiids were

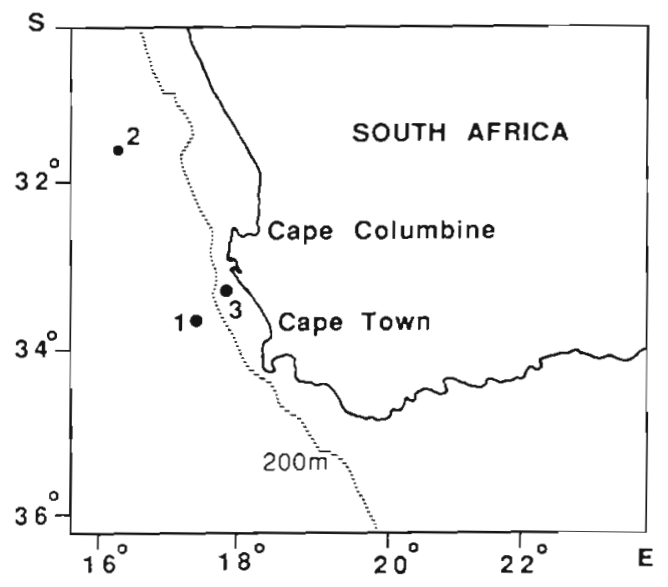

Fig. 1 Locations of sampling sites on Cruises 1 to 3 
collected by towing a Bongo net fitted with 300 and $900 \mu \mathrm{m}$ meshes at a speed of $<1 \mathrm{~m} \mathrm{~s}^{-1}$. During daylight the nets were towed to within a few meters of the bottom in an attempt to catch juvenile and adult stages, whereas at night sufficient numbers were collected by oblique tows to a depth of ca $50 \mathrm{~m}$. Adult and juvenile euphausiids were collected in the $900 \mathrm{~km}$ net, while furcilia and calyptopis larvae were retained by the $300 \mu \mathrm{m}$ net. Upon collection, samples were immediately processed for gut pigments as described below

During each cruise an estimate of euphausiid abundance was obtained at night by quantitative Bongo net hauls from $100 \mathrm{~m}$ to the surface with a $300 \mu \mathrm{m}$ mesh net. This material was preserved in $5 \%$ formalin for later enumeration of all developmental stages of Euphausia lucens. Vertical chlorophyll profiles were also recorded 2 to 4 times during the course of each $24 \mathrm{~h}$ experiment using a rosette sampler with 12 Niskin bottles. Water samples were taken at ca $10 \mathrm{~m}$ depth intervals down to $60 \mathrm{~m}$. Triplicate $100 \mathrm{ml}$ samples from each depth were filtered through a Whatman GF/F filter, which was then homogenized and extracted overnight at $-20^{\circ} \mathrm{C}$ in $11 \mathrm{ml} 90 \%$ acetone. Samples were then centrifuged for $10 \mathrm{~min}$ at $3200 \times \mathrm{g}$ and the fluorescence measured on a Turner Designs fluorometer before and after acidification with $10 \% \mathrm{HCl}$.

Gut pigment analysis. For the examination of diel feeding rhythms, euphausiids were collected at ca $3 \mathrm{~h}$ intervals over a period of $24 \mathrm{~h}$. At each time interval 10 to 15 replicate samples of each developmental stage were analyzed for total gut pigment content (chl + phaeopigments). Adults and juveniles were processed immediately on board ship, while the larval stages were frozen in liquid nitrogen for later processing. The total body length (tip of rostrum to distal end of telson) of each specimen was recorded under a dissecting microscope after which the euphausiids were immediately homogenized in $11 \mathrm{ml} 90 \%$ acetone. Samples were extracted overnight at $-20^{\circ} \mathrm{C}$ and the fluorescence read on a Turner Designs fluorometer before and after addition of acid. The chlorophyll (chl) and phaeopigment content of each euphausiid was calculated according to Dagg \& Walser (1987). A single adult (ca 11 to $17 \mathrm{~mm}$ length) contained sufficient pigment to be detected by the fluorometer, whereas 3 to 5 juveniles (ca 6 to $9 \mathrm{~mm}$ ) were required per extraction for reproducible results. Euphausiid dry mass was estimated from the length/weight regression given in Stuart (1986) and the mean length was used when more than one euphausiid was extracted per sample.

Aliquots of the larval stages of Euphausia lucens collected by the $300 \mu \mathrm{m}$ Bongo net were immediately filtered onto Whatman no. 1 filters, wrapped in foil and frozen in liquid nitrogen. A comparison between the pigment content of 10 adults analyzed immediately on board ship and those analyzed after being frozen for ca 1 wk in liquid nitrogen showed no significant difference between pigment content $(p<0.001)$, indicating that pigment loss due to freezing was negligible. In the laboratory, the filters were defrosted in a small quantity of filtered seawater and the larval stages rapidly picked out under a dissecting microscope and placed in $90 \%$ acetone. After 15 min of picking, the sample was discarded and a new sample analyzed. Between 5 and 10 furcilia larvae (ca 2.5 to $5.5 \mathrm{~mm}$ ) and 15 to 20 calyptopis larvae were extracted per sample to ensure a reliable fluorescence reading. Different stages of calyptopis larvae (CI, CII, CIII) and furcilia larvae (FI to FVI) were analyzed separately and the dry weight of each stage was obtained from previous measurements of larval weights (Stuart \& Pillar 1988). Large variations, particularly at night, were evident in the gut pigment content of individuals of each developmental stage with differences between euphausiids of the same size often being greater than between euphausids of a different size. For this reason, results have been grouped by stage (adult, juvenile, furcilia larvae and calyptopis larvae), and expressed as ng pigment per individual rather than on a dry weight basis

Herbivorous feeding. Ingestion rates of plant material were calculated from integrated gut pigment content and gut evacuation rates, according to Dagg \& Wyman (1983). Gut clearance rates of plant pigment were estimated on 5 separate occasions by placing a large number of adult euphausiids (collected between 21:00 and 22:00 h, when gut pigment levels were at a maximum) in $20 \mathrm{l}$ of $0.45 \mu \mathrm{m}$ filtered seawater and removing subsamples of 3 to 5 individuals at intervals ( 4 to $10 \mathrm{~min}$ ) over $1 \mathrm{~h}$ and then at $20 \mathrm{~min}$ intervals for a further 2 to $3 \mathrm{~h}$. Each euphausiid was immediately placed in a test tube containing $90 \%$ acetone and processed for gut pigment content as described earlier. Previous studies have indicated that the gut evacuation rate of zooplankton is negatively exponential (Dagg \& Wyman 1983) and can be expressed by the following equation:

$$
\mathrm{S}_{\mathrm{t}}=\mathrm{S}_{0} \mathrm{e}^{-\mathrm{kt}}
$$

where $\mathrm{S}_{\mathrm{t}}=$ gut pigment content at time $\mathrm{t}_{;} \mathrm{S}_{0}=$ initial level of gut pigments; $\mathrm{k}=$ gut evacuation rate (the reciprocal of which gives the gut passage time); and $t=$ time (min). Due to insufficient numbers, no gut evacuation experiments were carried out with juveniles or larvae. It was therefore assumed that $\mathrm{k}$ was constant for all-sized euphausiids, which may be realistic, since Peterson et al. (1990) found that gut evacuation rates of 4 different copepod taxa ranging in size from 3.6 to $81 \mu \mathrm{g} \mathrm{C}$ were remarkably constant. Ingestion rates of plant material were then calculated from the following relationship: 


$$
I=k S_{d} h_{d}+k S_{n} h_{n}
$$

where $\mathrm{I}=$ ingestion rate $\left(\mathrm{ng}\right.$ chl euph $\left.{ }^{-1} \mathrm{~d}^{-1}\right) ; \mathrm{k}=$ gut evacuation rate $\left(h^{-1}\right) ; S_{d}$ and $S_{n}=$ gut pigment levels of euphausiids in the field during day and night respectively; and $h_{d}$ and $h_{n}=$ number of hours of daylight or darkness, taken from sunrise to sunset. Pigment content per individual was obtained by integrating the area under the curve of pigment vs time. In the case of the larval stages in Cruise 3 , it was assumed that gut pigment levels from 09:00 to 14:00 h were constant, as in the other 2 cruises. Ingestion rates in terms of carbon were estimated assuming a C:chl ratio of $40: 1$, and the carbon ration ingested, in terms of \% body carbon, was obtained using a body carbon content of $40.43 \%$ of the dry weight (Stuart 1986).

Clearance rates can then be calculated from the following expression:

$$
\mathrm{F}=\mathrm{I} / \mathrm{C}
$$

where $F=$ clearance rate in $\mathrm{ml}$ euph. $.^{-1} \mathrm{~d}^{-1}, \mathrm{I}=$ ingestion rate of plant pigments (ng chl euph. ${ }^{-1} \mathrm{~d}^{-1}$ ); and $\mathrm{C}=$ average ambient chlorophyll concentration $(\mu \mathrm{g} \mathrm{chl}$ $\mathrm{l}^{-1}$ ) in the upper $30 \mathrm{~m}$ of the water column at each station. The grazing impact of euphausiids on the phytoplankton stocks at each station was then estimated from the product of the abundance of each developmental stage and their daily ingestion rates.

Carnivorous feeding. Carnivorous feeding by Euphausia lucens was investigated using preserved specimens which were collected at the same time as specimens used for gut pigment analysis. For each time interval, 20 adults were examined for evidence of carnivorous feeding. Relationships between euphausiid size, and the number and size of copepods consumed were also inspected by examining a number of smaller euphausiids from each cruise. The total length of each specimen was measured under a dissecting microscope and the stomach removed and placed on a glass slide. The stomach contents were teased out, and a small amount of the chitin stain azo black was added and the slide examined under $400 \times$ magnification for the presence of copepod remains and in particular, copepod mandibles. The width of each mandibular blade was measured and the number of copepods consumed estimated from the total number of mandible pairs per stomach. Mandible pairs of each prey item in the gut were easily matched by their shape and dimensions, since the toothed edge of the mandibular blade is characteristic for each species of copepod (Sullivan et al. 1975). In most cases, both sets of mandibles were found, and when only a single mandible was present it was nevertheless counted as one copepod. A few stomachs contained copepod remains but no mandibles and these were assumed to contain at least one copepod. The size of prey consumed by euphausiids was estimated from $\mathrm{Eq}$. (4), relating mandible width to copepod prosome length, obtained from a mixed assemblage of copepods:

$$
\mathrm{L}=-0.0721+0.0140 \mathrm{~W}, \mathrm{r}^{2}=0.94
$$

where $\mathrm{L}=$ copepod prosome length $(\mathrm{mm})$; and $\mathrm{W}=$ copepod mandible width $(\mu \mathrm{m})$.

For the calculation of ingestion rates of copepod prey, 4 gut evacuation experiments were performed in a similar fashion to evacuation of gut pigments. A large number of adult euphausiids were placed in $20 \mathrm{l}$ of $0.45 \mu \mathrm{m}$ filtered seawater as before, and 5 individuals removed at 5 to $10 \mathrm{~min}$ intervals for $1 \mathrm{~h}$, then at 20 to $60 \mathrm{~min}$ intervals for a period of up to $5 \mathrm{~h}$. Samples were immediately preserved in $5 \%$ formalin for later enumeration of mandible pairs.

Ingestion rates were calculated by integrating the area under the curve of number of mandible pairs versus time. For Cruise 2, it was assumed that the number of mandible pairs per stomach decreased linearly with time from 05:15 to 10:00 h. The ingested ration, in terms of carbon, was obtained by calculating the mean size of copepod consumed during each cruise, estimating its dry mass from Eq. (5) (after James 1987 ) and assuming a carbon content of $46 \%$ of the dry mass (Vidal 1980):

$$
\mathrm{DM}=19.425 \mathrm{~L}^{2.59}
$$

where $\mathrm{DM}=$ copepod dry weight $(\mu \mathrm{g}) ;$ and $\mathrm{L}=$ copepod prosome length $(\mathrm{mm})$.

\section{RESULTS}

\section{Diel feeding rhythms}

Adult Euphausia lucens exhibited pronounced diel feeding rhythms on phytoplankton cells in all 3 cruises, with up to 100 -fold increases in gut pigment levels being observed at night (Fig. 2). Variability in gut pigments among replicate samples was high, especially at night, indicating natural intrinsic variations in the feeding rates on phytoplankton cells.

Maximum gut pigment levels also varied widely between cruises, with the mean maximum gut pigment content ranging from ca $23 \mathrm{ng}$ pigment per individual on Cruise 2 to ca $250 \mathrm{ng}$ pigment per individual on Cruise 3. These differences were related to ambient chlorophyll concentrations in the upper $30 \mathrm{~m}$ of the water column, with the highest concentrations (up to $18 \mu \mathrm{g} \mathrm{chl}^{-1}$ ) being recorded on Cruise 3 and very low levels (ca $0.7 \mu \mathrm{g} \mathrm{chl}^{-1}$ ) being recorded throughout the water column in Cruise 2 (Fig. 3). 


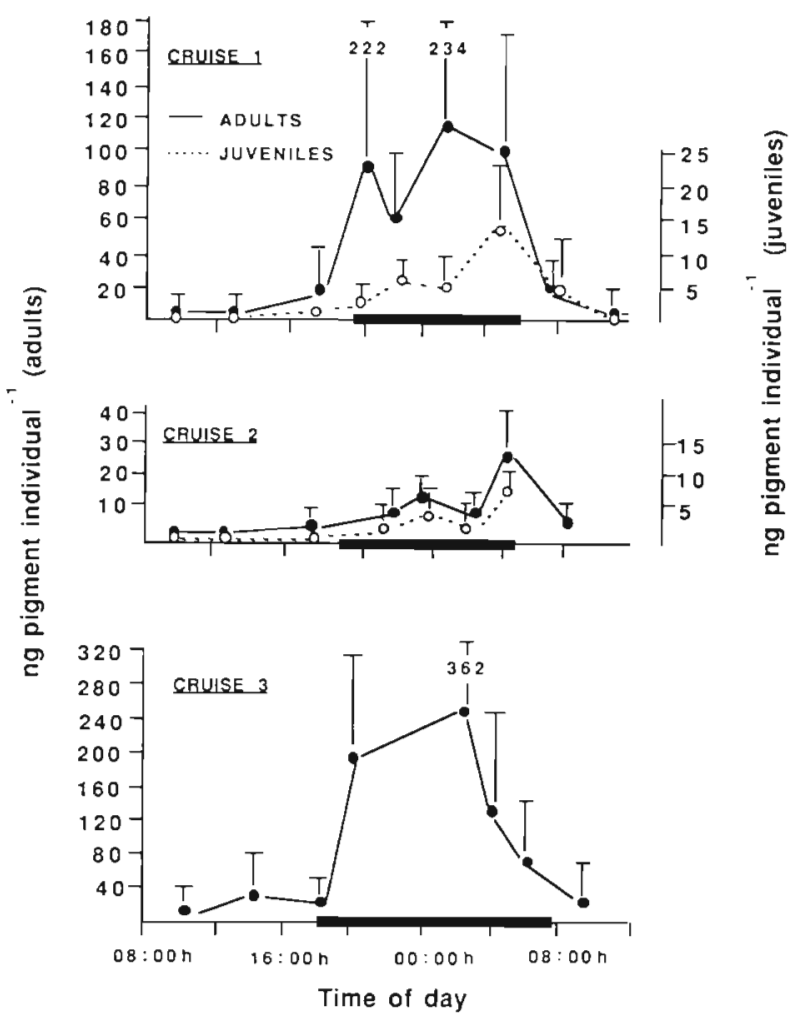

Fig. 2. Euphausia lucens. Diel variations in gut pigment levels $(+1 \mathrm{SD})$ of adults and juveniles on Cruises 1 to 3. Dark horizontal bars represent hours of darkness

Chlorophyll $\left(\mu \mathrm{g} \mathrm{I}^{-1}\right)$

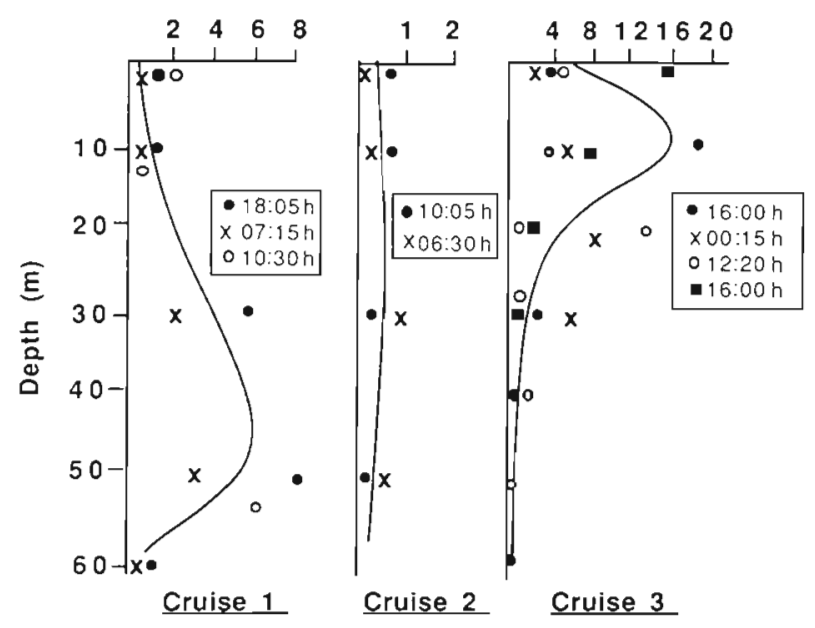

Fig. 3. Chlorophyll-depth profiles obtained during each $24 \mathrm{~h}$ feeding experiment

Gut pigment levels of juveniles, albeit much lower than those of the adults, followed the same trends, with a marked nocturnal increase in feeding on chl-containing particles (Fig. 2). Feeding rhythms of juveniles in Cruise 3 could not be ascertained due to insufficient numbers of individuals present. Furcilia larvae, on the other hand, did not consistently exhibit such clear diurnal feeding rhythms as those of the juveniles and adults. On Cruises 2 and 3, somewhat higher levels of gut pigments were recorded during darkness, while on Cruise 1 no evidence of diel feeding rhythms was observed (Fig.4). In contrast, calyptopis larvae never exhibited diel feeding rhythms, with gut pigment levels being similar during the day and night. However, in all cases stomach pigment content was highly size-dependent (Table 1) with the slopes of the allometric equations relating body dry weight to gut pigment content being similar, but the elevations varying significantly between cruises (Cruises 1 and 2, p < 0.01; 1 and 3 , $\mathrm{p}<0.01 ; 2$ and $3, \mathrm{p}<0.001$ ) (Zar 1984), presumably due to differences in ambient chl levels.
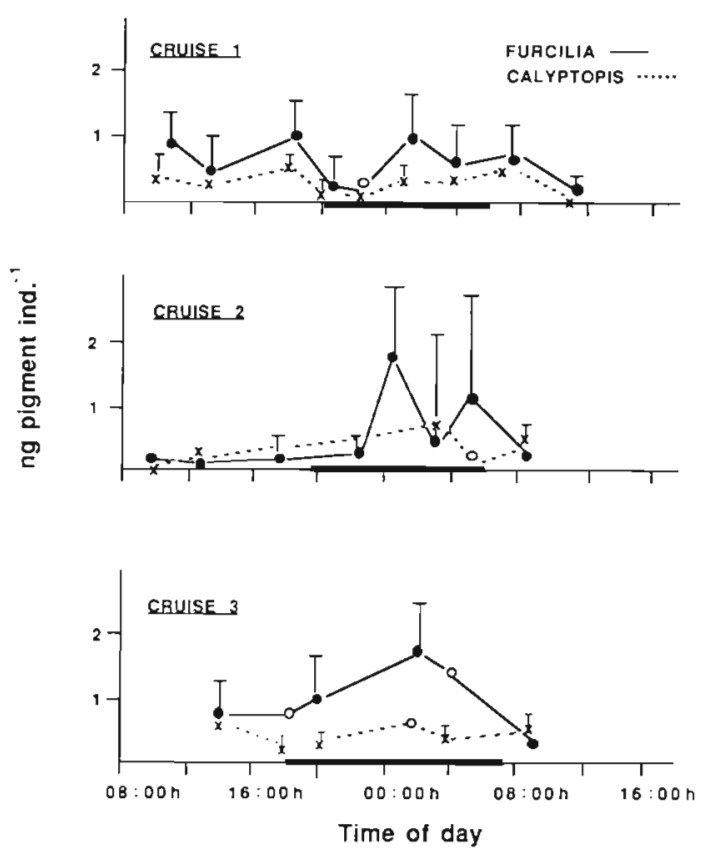

Fig. 4. Euphausia lucens. Diel variations in gut pigment levels (+ 1 SD) of furcilia and calyptopis larvae during Cruises 1 to 3 . (o) Single samples; dark horizontal bars represent hours of darkness

Table 1. Euphausia lucens. Parameters of allometric equations describing the relationship between nocturnal gut pigment content $\left(P\right.$; ng pigment ind. ${ }^{-1}$ ) and body dry weight $(W ; \mathrm{mg})$ for Cruises 1 to $3 . \mathrm{P}=\mathrm{aW}^{\mathrm{b}}$

\begin{tabular}{|crcc|}
\hline Cruise & a & b & $\mathrm{r}^{2}$ \\
\hline 1 & 8.28 & 0.95 & 0.74 \\
2 & 3.36 & 0.91 & 0.63 \\
3 & 29.78 & 0.83 & 0.83 \\
\hline
\end{tabular}


In the case of the adults, the relative proportions of chlorophyll and phaeopigments in the stomach contents differed between day and night, with phaeopigments being more abundant at night. Low gut pigment levels in the day were associated with a high percentage of chl (up to $90 \%$ ) while gut pigments at night contained only ca $10 \%$ chlorophyll (Fig. 5). This may be indicative of low digestion rates during the day, since very little of the chlorophyll has been broken down and converted to phaeopigments, while at night the converse holds true. Larval stages, on the other hand, had variable proportions of chlorophyll during the day and night, suggesting continual feeding and digestion over a $24 \mathrm{~h}$ period.

\section{Carnivorous feeding}

Consumption of copepod prey by adult euphausiids was estimated from the mean number of copepod mandible pairs per stomach (Fig. 6). The maximum mean number of mandible pairs ranged from 1.4 to 4.1 per euphausiid stomach, with carnivory on copepods being largely confined to daylight on Cruises 1 and 3 . In contrast, substantial numbers of copepods were consumed at night on Cruise 2. Ambient chlorophyll con-
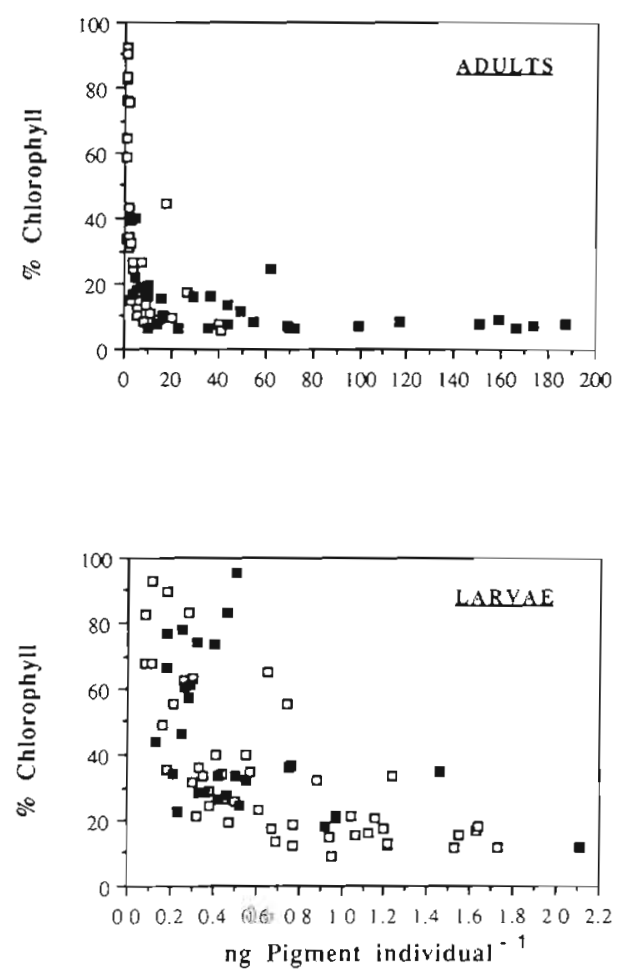

Fig. 5. Euphausia lucens. Relationship between gut pigment content and percentage chlorophyll in the guts of adults and larvae from Cruise 1 ( $\square$ Samples collected at night, $\square$ ) day samples centrations were particularly low during this cruise, which may have provoked the switch to a carnivorous diet. It is also apparent from Fig. 6 that the mean number of mandible pairs per euphausiid is indirectly related to the gut pigment content, especially during darkness. This relationship is further illustrated in Fig. 7 .

Copepod mandibles were found in juvenile stomachs on relatively few occasions, indicating that carnivory is predominantly confined to adults. The number of prey items eaten was related to euphausiid size, with up to 8 pairs of mandibles being found in adult stomachs and only 1 or 2 in the guts of the juveniles. As an example of this relationship, results from Cruise 2 are presented in Fig. 8. Copepod mandibles were found in furcilia larvae on only 4 occasions, although copepod remains were sometimes encountered

As determined from mandible widths, copepods ranging in size from 0.15 to $2.19 \mathrm{~mm}$ prosome length were consumed by adult Euphausia lucens, with the mean size varying between $0.54 \mathrm{~mm}$ (Cruise 2) and $0.86 \mathrm{~mm}$ prosome length (Cruise 3). The size-frequency distribution of copepods in the guts, as well as in the
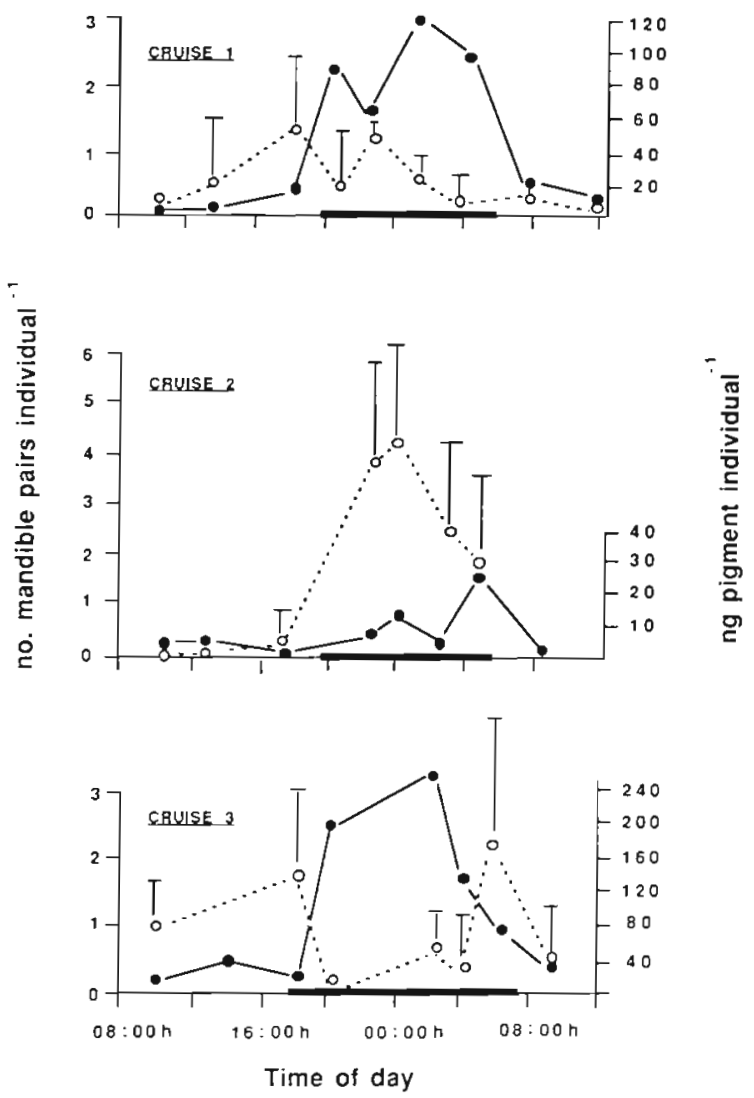

Fig. 6. Euphausia lucens. Diel variations in number (c) of mandible pairs $(+1 \mathrm{SD})$ in the stomachs of adults superimposed on gut pigment levels $(\bullet)$, during Cruises 1 to 3 


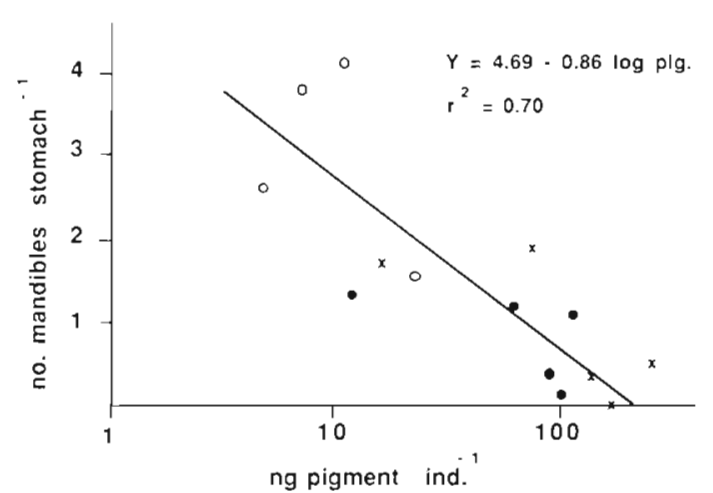

Fig. 7. Euphausia lucens. Relationship between gut pigment content of adults at night and number of mandible pairs per stomach, for Cruises $1(\bullet), 2(0)$ and $3(x)$

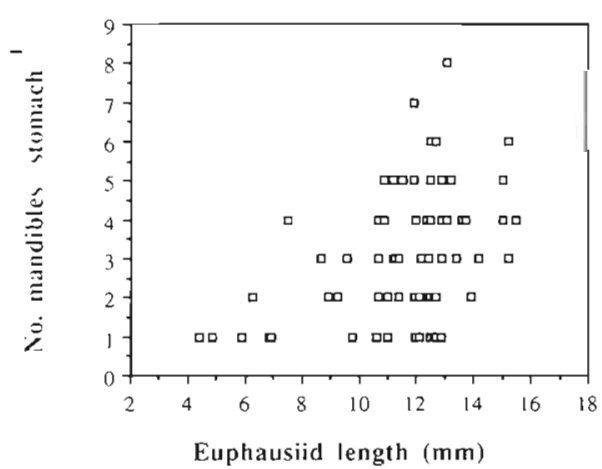

Fig. 8. Euphausia lucens. Results from Cruise 2 showing the relationship between euphausiid length and number of copepod mandible pairs per stomach

water column for each cruise, are presented in Fig. 9. Unfortunately, the $300 \mu \mathrm{m}$ mesh did not quantitatively retain the smaller copepods (Pillar 1984b), but it is nevertheless apparent that the size frequency of copepods consumed reflects the size distribution in the water column. Some idea of the density of copepods present during each cruise can be obtained from the numbers retained by the $300 \mu \mathrm{m}$ net. Copepod abundances during all 3 cruises were of the same order of magnitude, ranging from $394 \mathrm{~m}^{-3}$ for Cruise 2 to $455 \mathrm{~m}^{-3}$ for Cruise 1 and $810 \mathrm{~m}^{-3}$ for Cruise 3. No clear relationship was found between predator size and size of copepod prey consumed, particularly amongst adult euphausiids (Fig. 10).

\section{Gut evacuation rates}

Of the 5 attempts to measure gut evacuation rate of plant pigments, 2 were discarded since no consistent decrease in gut pigments was observed during the first hour. Gut passage times of the other 3 experiments
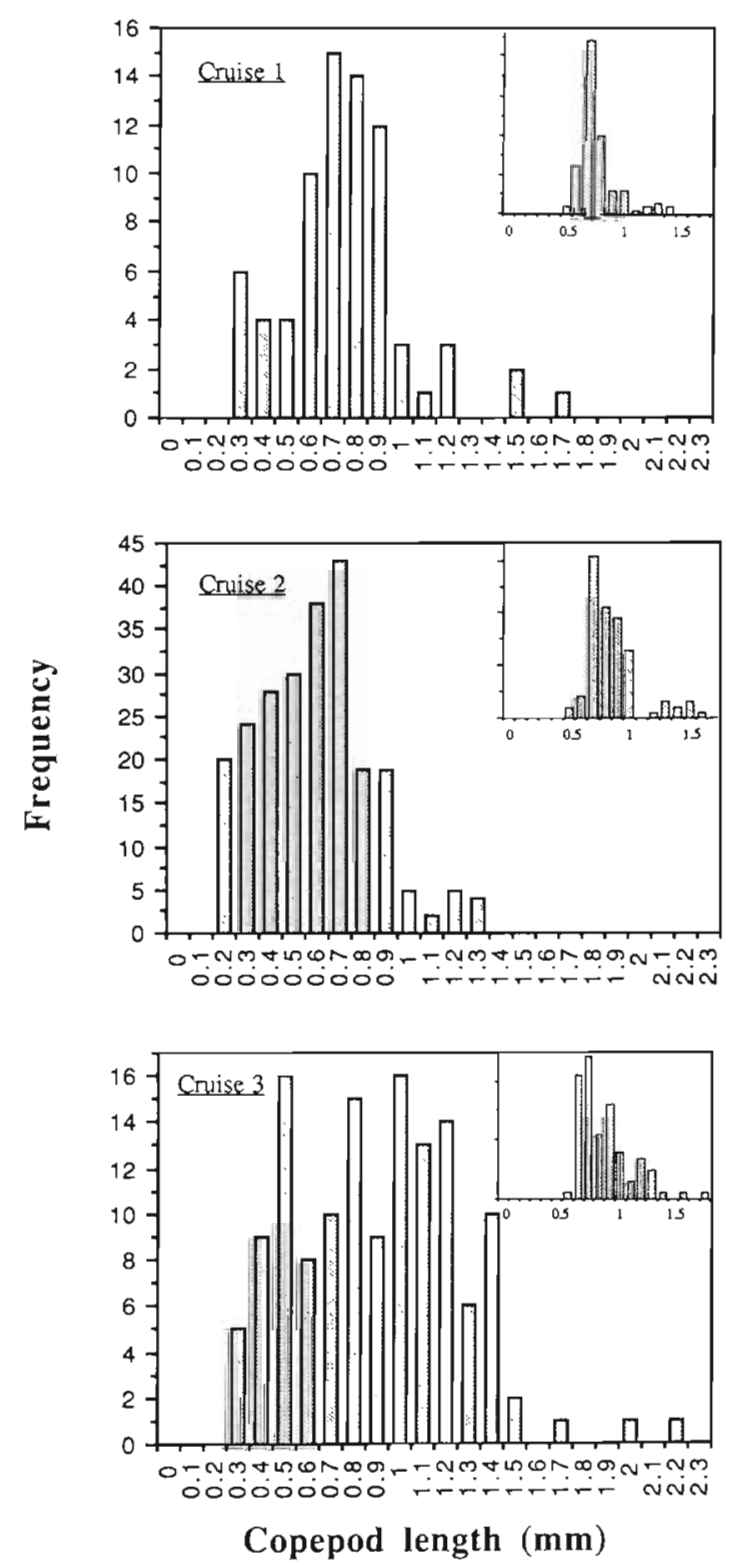

Fig. 9. Size frequency distribution of copepods (prosome length) in the guts of adult Euphausia lucens during Cruises 1. 2 and 3, with an insert of the size frequency of copepods in the water column retained by the $300 \mu \mathrm{m}$ net

ranged from 38.5 to $90 \mathrm{~min}$ (Table 2). Gut passage times of copepod mandibles were calculated in a similar manner, but due to high variability among replicate samples, the mean number of mandibles from each time interval was used in constructing the exponential equations. Results from 2 gut evacuation experiments were also discarded due to the absence of a regular decrease in the number of copepod mandibles during the first hour. Since gut evacuation rates are greatly influenced by the length of the gut clearance experiments (Huntley et al. 1987) we assumed that only the 


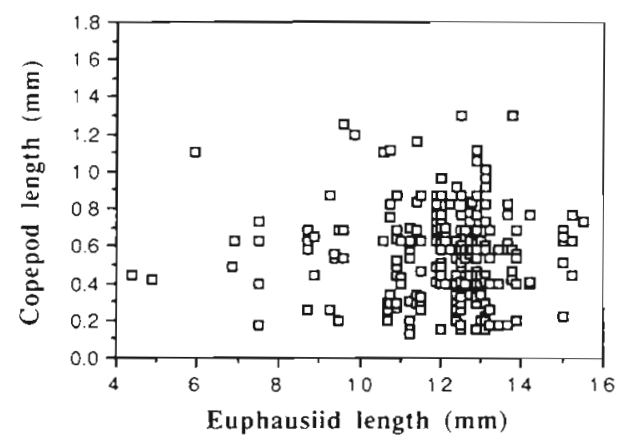

Fig. 10. Results from Cruise 2 showing the relationship between Euphausia lucens size (total length) and size of prey consumed (copepod prosome length)

Table 2. Euphausia lucens. Gut evacuation rates of plant pigments and copepod mandibles, using an exponential model with data from the first 60 min to describe rates. $S_{0}$ : initial level of gut contents (ng pigment or no. mandible pairs) k: gut evacuation rate

\begin{tabular}{|ccccc|}
\hline So & $\begin{array}{c}\mathrm{k} \\
\left(\mathrm{min}^{-1}\right)\end{array}$ & $\begin{array}{c}\mathrm{k} \\
\left(\mathrm{h}^{-1}\right)\end{array}$ & $\begin{array}{c}\text { Gut passage } \\
\text { time (min) }\end{array}$ & $\mathrm{p}$ \\
\hline Pigments & & & & \\
77.62 & -0.011 & 0.66 & 90.9 & $<0.005$ \\
111.68 & -0.026 & 1.56 & 38.5 & $<0.001$ \\
100.46 & -0.017 & 1.02 & 58.8 & $<0.001$ \\
Mandibles & & & & \\
2.41 & -0.010 & 0.60 & 100.0 & $<0.10$ \\
3.04 & -0.013 & 0.78 & 76.9 & $<0.01$ \\
\hline
\end{tabular}

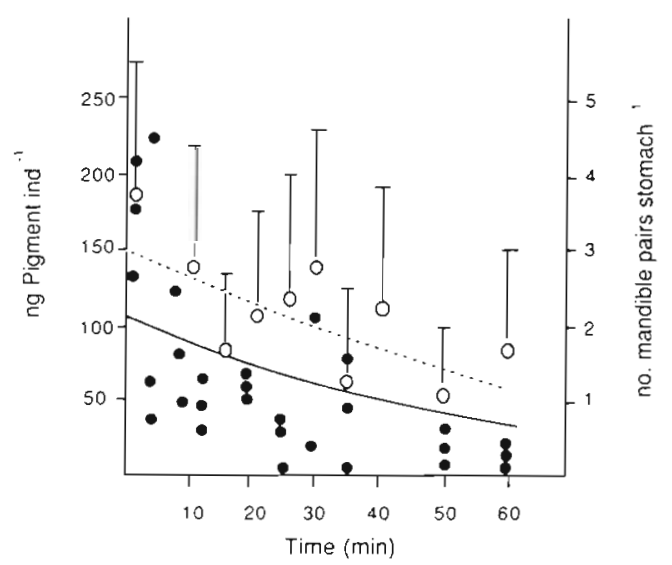

Fig. 11. Euphausia lucens. Representative gut evacuation rate data for gut pigments $(\bullet-\bullet)$ and copepod mandibles $1+1$ SD) (..) by adults, measured on Cruise 3. $\mathrm{S}_{\mathrm{t}}=100.46 \mathrm{e}^{-0.017 t}, \mathrm{r}^{2}=0.55$ (pigment); and $\mathrm{S}_{1}=3.04 \mathrm{e}^{-0.013 t}$, $r^{2}=0.43$ (mandibles); where $S_{t}$ is gut content at time $t$

data from the initial 60 min of each experiment were relevant, which is comparable to the gut passage time of Euphausia pacifica (Willason \& Cox 1987). Fir 11 shows representative gut evacuation data for both gut pigments as well as copepod mandible pairs. Willason \& Cox (1987) found that gut evacuation rates of $E$. pacifica were lower for starved individuals $(1.67 \mathrm{~h})$ than feeding euphausiids $(1.08 \mathrm{~h})$ due to retention of food in their guts when not feeding. For this reason gut evacuation rates of $E$. lucens in filtered seawater may have been underestimated, so the maximum gut evacuation rate that fits the level of significance $p<0.01$ was used in the calculation of ingestion rates (i.e. $38.5 \mathrm{~min}$ for gut pigments and $76.9 \mathrm{~min}$ for copepod mandibles).

\section{DISCUSSION}

\section{Diel variations in gut pigments}

Diel variations in grazing rates on phytoplankton cells have frequently been observed for many species of euphausiids (Sameoto 1981, Simmard et al. 1986, Willason \& Cox 1987) as well as copepods (Head et al. 1985, Huntley et al. 1987). Generally, feeding rhythms were associated with nocturnal vertical migrations into the euphotic zone, although diel feeding rhythms have also been observed in several non-migrating copepod species (Hayward 1980, Head et al. 1984, Huntley et al. 1987). In the present study, grazing activity in Euphausia lucens appears to be strongly correlated with vertical migratory behaviour, which in turn is probably controlled by light intensity, either directly or via endogenous feeding rhythms. E. lucens, like most other euphausiid species, exhibits ontogenetic vertical migrations: the older furcilia larvae migrate more extensively than the younger calyptopis larvae, which are generally restricted to the surface layers, while the adults and juveniles are found in the bottom layers of the water columm during the day and in the surface layers at night (Pillar et al. 1989). This migratory pattern is also reflected in the feeding rhythms of the various developmental stages. Adults and juveniles always exhibit pronounced diel feeding rhythms, the furcilia larvae tending to feed more at night, while the calyptopis larvae show no evidence of diel feeding rhythms.

Phytoplankton concentration had little effect on these feeding rhythms, since marked nocturnal increases in gut pigment levels were observed in all 3 cruises, even at very low chlorophyll concentrations. However, maximum gut pigment levels in the adults were drastically reduced when phytoplankton concentrations were low, whereas the larval stages were not affected to the same extent (see Fig. 4). Since the proportion of ingested chlorophyll degraded to nonfluorescent by-products is variable (Lopez et al. 1988), 
and may change from cruise to cruise or with the abundance of phytoplankton available, these results should be interpreted with caution. Nevertheless, it would appear that the threshold below which clearance rates decline are stage-specific and that the larvae could ingest sufficient chlorophyll to meet their daily energy requirements even at very low food levels. Also, the critical concentration at which maximum ingestion rates are achieved must be greater for the adults than for the larvae. For this reason the larval stages are better able to cope in dilute food environments and would not require supplementation by an alternative food source. In addition, it should be noted that not all the chlorophyll present in the water column is available to the adult euphausiids. In the present study, 36 to $85 \%$ of the chlorophyll was from particles $<10 \mu \mathrm{m}$ in diameter, and previous studies have shown that adult Euphausia lucens cannot efficiently filter particles of this size (Stuart 1989). However, Marschall (1985) found that the feeding appendages of E. superba larval stages differed morphologically from those of the adults, and suggested that krill larvae might be able to feed on particles with a minimum diameter of only $1 \mu \mathrm{m}$. It is likely that the larval stages of E. lucens may also be able to utilise smaller particles more efficiently than the adults and thereby exploit a greater proportion of the available food.

Gut phaeopigments, presumably produced by the rapid degradation of chlorophyll in the gut, were generally more abundant than chlorophyll in adult stomachs at night, comprising up to $90 \%$ of total gut pigments (see Fig.5). Furthermore, the proportion of chlorophyll was inversely related to the gut pigment content. This phenomenon has also been noted by Antezana \& Ray (1984) and Simmard et al. (1986) which they attributed to the proportion of fragmented cells in the gut relative to the total amount ingested. Those stomachs with a high phytoplankton content would have a large proportion of fragmented cells with the chlorophyll being degraded to phaeopigments, whereas stomachs with few phytoplankton cells (such as during the dayl would have variable proportions of intact cells. This day/night relationship in percentage chlorophyll was not evident for the larval stages (see Fig. 5), since diel feeding rhythms were largely absent. However, larvae with full guts generally had a lower proportion of chlorophyll than those with small amounts of pigment in their guts, regardless of the time of day.

\section{Carnivorous feeding}

An optimally foraging species would be expected to consume the largest size of prey possible in order to gain the greatest energy returns. However, adult
Euphausia lucens consumed prey over a wide size range (Fig. 10) suggesting that they are predominantly opportunistic feeders. Under conditions of high phytoplankton concentrations, adult E. lucens exhibited a diurnal change in diet from feeding on copepods during the day to grazing on phytoplankton at night. Sameoto (1981) observed a similar diurnal change in diet in the euphausiid Meganyctiphanes norvegica, which fed on copepods at depth during the day and on phytoplankton and copepods in the surface layers at night. However, when chlorophyll levels were low, E. lucens changed its feeding strategy and fed predominantly on copepods at night (see Fig. 6, Cruise 2), even though copepod numbers (retained by the $300 \mu \mathrm{m}$ net) were relatively low during this cruise. This implies that the switch in feeding behaviour between herbivory and carnivory is triggered by ambient phytoplankton concentrations, and is supported by the observation that gut pigment levels at night were inversely related to the number of copepods per stomach (Fig. 7). Nocturnal carnivory thus appears to predominate only when phytoplankton is scarce and gut pigment levels are low. Although E. lucens is capable of ingesting small quantities of phytoplankton cells at low chlorophyll concentrations (see Fig. 2, Cruise 2), the energy returns are presumably not as great as when consuming copepod prey, so under these conditions its diet will consist predominantly of copepod prey. This increased tendency for predatory behaviour when alternative food sources are limited has also been noted for several species of omnivorous copepods (Landry 1981, Daan et al. 1988). Likewise, Turner (1984) observed an increase in the occurrence of crustacean appendages in faecal pellets of the copepod Eucalanus pileatus at stations where phytoplankton concentrations were low.

Calyptopis and furcilia larvae of Euphausia lucens are largely herbivorous, while the juveniles consume relatively few copepods. This is consistent with the results of Mauchline (1966), who noted that younger individuals of the euphausiids Meganyctiphanes norvegica and Thysanoessa raschii filter-feed on phytoplankton to a greater extent while older individuals eat more crustaceans. Feeding rates and the overall nature of the diet of E. lucens are thus influenced by a number of interrelated factors. Variables such as time of day, stage of development and phytoplankton concentration will all have an effect on food preferences and the degree of herbivory and carnivory found in the diet. In the southern Benguela upwelling region, which is subjected to episodic pulses of high phytoplankton concentrations as well as periods of reduced food availability, it is obviously advantageous for zooplankton organisms to feed omnivorously and thus exploit a wide range of food conditions. This is in accordance with the theory postulated by Isaacs $(1972,1977)$ that marine 
planktonic food-webs are trophically unstructured, and that most pelagic animals must feed omnivorously during all or part of their life times. This study also demonstrates the inherent plasticity of feeding behaviour by $E$. lucens under varying food conditions and emphasizes the importance of flexibility in feeding modes according to environmental conditions.

\section{Ingestion rates}

In situ ingestion rates of phytoplankton and copepods by Euphausia lucens were calculated from gut contents and gut evacuation rates. Table 3 gives the integrated gut pigment content for each developmental stage of E. lucens and ingestion rates on plant pigment, while Table 4 shows the carbon-specific ingestion rates and clearance rates on phytoplankton cells. Data for copepod ingestion rates by adults are given in Table 5, while the relative contributions of herbivory and carnivory are shown in Table 6. During conditions of relatively high ambient chlorophyll levels (Cruises 1 and 3), herbivory contributed 60 to $63 \%$ of the total carbon ingested, with carnivory on copepods supplying the remaining proportion of carbon ingested. However, under conditions of low phytoplankton concentrations (Cruise 2) carnivory was more pronounced, contributing ca $85 \%$ of the total $\mathrm{C}$ ingested.

Ingestion rates calculated using the gut fluorescence technique are subject to numerous sources of error (see Head 1988, Lopez et al. 1988). According to Huntley et al. (1987), ingestion rates are greatly influenced by the gut evacuation rate $(\mathrm{k})$, which in turn is affected by the length of the gut clearance experiments. In the present study, this was calculated over a period of $1 \mathrm{~h}$, but faster gut turnover times are obtained if a shorter time interval is used. Errors may also arise due to pigment loss through digestion or degradation to non-fluorescent particles, but the extent of this is still controversial (Conover et al. 1986, Dagg \& Walser 1987, Dam \& Peterson 1988) and may vary with the nutritional state of the grazer (Lopez et al. 1988). Furthermore, temperature is known to greatly affect gut evacuation rates (Kiorboe et al. 1982, Dagg \& Wyman 1983) and although the surface temperatures in all 3 studies were similar $\left(\mathrm{ca} 16^{\circ} \mathrm{C}\right)$, the temperature at the bottom of the water column would be considerably lower. Depending on where in the water column digestion takes place, there is a possibility that ingestion rates may have been overestimated.

Despite these potential sources of error, carbonspecific ingestion rates of aduit Euphausia lucens feeding herbivorously compare well with those reported in the literature for other euphausiid species (Table 7 ). Ingestion rates ranged from 0.69 to $8.42 \%$ body $C \mathrm{~d}^{-1}$, which is similar to the values reported for E. pacifica and E. superba. Clearance rates of 320 to $1403 \mathrm{ml}$ ind. ${ }^{-1} \mathrm{~d}^{-1}$ (equivalent to 4.5 to $15.1 \mathrm{ml} \mathrm{mg}^{-1} \mathrm{~h}^{-1}$ ) are, however, somewhat higher than the laboratory-measured rates of 1 to $3 \mathrm{ml} \mathrm{mg}^{-1} \mathrm{~h}^{-1}$ for E. lucens grazing natural phytoplankton suspensions (Stuart 1989). However, large discrepancies in the clearance rates of many euphausiid species are frequently encountered in the literature, depending on the techniques used to meas-

Table 3. Euphausia lucens. Gut pigment content during the day and night and ingestion rates of plant pigment, for the various developmental stages, during Cruises 1 to 3

\begin{tabular}{|c|c|c|c|c|c|}
\hline & \multicolumn{2}{|c|}{ Gut pigments (ng ind. ${ }^{-1}$ ) } & \multicolumn{3}{|c|}{ Ingestion (ng pigment. ind ${ }^{-1}$ ) } \\
\hline & Day & Night & Day & Night & Total \\
\hline \multicolumn{6}{|l|}{ Cruise 1} \\
\hline Adults & 7.89 & 91.51 & 172.32 & 1427.56 & 1599.87 \\
\hline JuveniJes & 1.60 & 6.74 & 34.94 & 105.14 & 140.09 \\
\hline Furcilia & 0.74 & 0.54 & 16.16 & 8.42 & 24.59 \\
\hline Calyptopis & 0.37 & 0.25 & 8.08 & 3.90 & 11.98 \\
\hline \multicolumn{6}{|l|}{ Cruise 2} \\
\hline Adults & 1.14 & 11.52 & 24.90 & 179.71 & 204.61 \\
\hline Juveniles & 0.46 & 4.19 & 10.05 & 65.36 & 75.41 \\
\hline Furcilia & 0.10 & 0.86 & 2.18 & 13.42 & 15.60 \\
\hline Calyptopis & 0.14 & 0.40 & 3.06 & 6.24 & 9.30 \\
\hline \multicolumn{6}{|l|}{ Cruise 3} \\
\hline Adults & 25.42 & 162.5 & 436.21 & 3295.50 & 3731.71 \\
\hline Juveniles & - & - & - & - & - \\
\hline Furcilia & 0.63 & 1.44 & 1081 & 29.20 & 40.01 \\
\hline Calyptopis & 0.49 & 0.51 & 8.41 & 10.34 & 18.75 \\
\hline
\end{tabular}


Table 4. Euphausia lucens. Ingestion rates of plant pigment (in terms of carbon) by the various developmental stages, as well as carbon ration, average ambient chlorophyll concentrations and clearance rates

\begin{tabular}{|c|c|c|c|c|c|}
\hline & $\begin{array}{l}\text { Body wt } \\
\text { (mg C) }\end{array}$ & $\begin{array}{l}\text { Ingestion } \\
\left(\mu g \mathrm{Cd}^{-1}\right)\end{array}$ & $\%$ Body C & $\begin{array}{c}\mathrm{Chl} \\
\left(\mu \mathrm{g} \mathrm{l} \mathrm{l}^{-1}\right)\end{array}$ & $\begin{array}{c}\text { Clearance } \\
\left(\mathrm{ml} \text { ind. }{ }^{-1} \mathrm{~d}^{-1}\right)\end{array}$ \\
\hline \multicolumn{6}{|l|}{ Cruise 1} \\
\hline Adults & 1.544 & 63.99 & 4.15 & 1.14 & 1403.40 \\
\hline Juveniles & 0.322 & 5.60 & 1.74 & 1.14 & 122.88 \\
\hline Furcilia & 0.031 & 0.98 & 3.15 & 1.14 & 21.57 \\
\hline Calyptopis & 0.010 & 0.48 & 4.79 & 1.14 & 10.51 \\
\hline \multicolumn{6}{|l|}{ Cruise 2} \\
\hline Adults & 1.180 & 8.18 & 0.69 & 0.64 & 319.70 \\
\hline Juveniles & 0.339 & 3.02 & 0.89 & 0.64 & 117.83 \\
\hline Furcilia & 0.051 & 0.62 & 1.22 & 0.64 & 24.38 \\
\hline Calyptopis & 0.011 & 0.37 & 3.32 & 0.64 & 14.53 \\
\hline \multicolumn{6}{|l|}{ Cruise 3} \\
\hline Adults & 1.772 & 149.27 & 8.42 & 4.96 & 752.36 \\
\hline Juveniles & - & - & - & - & - \\
\hline Furcilia & 0.028 & 1.60 & 5.72 & 4.96 & 8.07 \\
\hline Calyptopis & 0.008 & 0.75 & 9.87 & 4.96 & 3.78 \\
\hline
\end{tabular}

Table 5. Euphausia lucens. Numbers of copepods per adult euphausiid stomach during the day and night on Cruises 1 to 3 , and ingestion rates expressed in terms of numbers, carbon and \% body carbon. Mean size of copepods consumed during each cruise is also indicated

\begin{tabular}{|c|c|c|c|c|c|c|c|c|}
\hline & \multicolumn{2}{|c|}{ No. copepods. ind ${ }^{-1}$} & \multicolumn{3}{|c|}{ Ingestion (no. ind. ${ }^{-1}$ ) } & \multirow{2}{*}{$\begin{array}{c}\text { Copepod } \\
\text { size }(\mu g \mathrm{C})\end{array}$} & \multirow{2}{*}{$\begin{array}{l}\text { Ingestion } \\
\left(\mu g \mathrm{Cd}^{-1}\right)\end{array}$} & \multirow[t]{2}{*}{$\%$ Body C } \\
\hline & $\operatorname{Day}( \pm \mathrm{SD})$ & Night $( \pm S D)$ & Day & Night & Total & & & \\
\hline Cruise 1 & $0.58(0.44)$ & $0.56(0.36)$ & 6.33 & 4.37 & 10.70 & 3.62 & 38.74 & 2.51 \\
\hline Cruise 2 & $0.40(0.53)$ & $2.75(0.89)$ & 4.37 & 21.45 & 25.82 & 1.81 & 46.73 & 3.96 \\
\hline Cruise 3 & $1.16(0.43)$ & $0.64(0.57)$ & 9.95 & 6.49 & 16.44 & 5.99 & 98.49 & 5.56 \\
\hline
\end{tabular}

Table 6. Euphausia lucens. Carbon ingestion by adults in the form of phytoplankton and copepods during Cruises 1 to 3 , as well as total carbon-specific ingestion rates and relative contributions of herbivory and carnivory in the diet

\begin{tabular}{|c|c|c|c|c|c|c|}
\hline & \multicolumn{3}{|c|}{ Ingestion $\left(\mu \mathrm{g} \mathrm{C}^{-1}\right)$} & \multirow[t]{2}{*}{$\%$ Body C } & \multirow[t]{2}{*}{$\%$ Herbivory } & \multirow[t]{2}{*}{$\%$ Carnivory } \\
\hline & Phytoplankton & Copepods & Total & & & \\
\hline Cruise 1 & 63.99 & 38.74 & 102.73 & 6.65 & 62.29 & 37.71 \\
\hline Cruise 2 & 8.18 & 46.73 & 54.91 & 4.65 & 14.90 & 85.11 \\
\hline Cruise 3 & 149.27 & 98.49 & 247.76 & 13.98 & 60.25 & 39.75 \\
\hline
\end{tabular}

ure them. The use of relatively small containers has been found to depress clearance rates of E. superba (Price et al. 1988), and Morris (1984) concluded that the true levels of filtration for E. superba are actually much higher than most laboratory studies indicate.

Little information is available on feeding rates of furcilia and calyptopis larvae of Euphausia lucens, but one would expect the carbon-specific ingestion rates to be substantially higher than for the adults. It is likely that these rates have been underestimated since the gut evacuation rate was assumed to be the same as for the adults, but may in reality be much faster. Values presented in Table 4 should therefore be regarded as minimum estimates. Nevertheless, there was a good agreement between body dry mass and ingestion and clearance rates, with weight-specific coefficients of 0.86 and 0.90 respectively (Table 8 ). This is similar to the weight-specific coefficient for carbon ingestion of 
Table 7. Euphausia spp. Carbon-specific ingestion rations of plant and animal (copepod) material by various euphausiid species, expressed as \% body carbon per day

\begin{tabular}{|lccll|}
\hline Species & \multicolumn{2}{c}{ Food source } & Conditions & Source \\
& Plant & Animal & & \\
\hline E. superba & $8.5 \%$ & $(83 \%$ min. resp. req.) & Lab experiments & Price et al. (1988) \\
E. pacifica & $15 \%$ & - & In situ bloom & Parsons et al. (1967) \\
E. pacifica & $4.4-13.8 \%$ & - & Lab experiments & Ross (1979) \\
E. pacifica & $6.3 \%$ & $0.45 \%$ & Lab experiments $\left(156 \mu \mathrm{g} \mathrm{C}^{-1}\right)$ & Ohman (1984) \\
E. pacifica & $0.8-6.8 \%$ & - & In situ gut fluorescence & Willason \& Cox (1987) \\
E. lucens & $11 \%$ & $8 \%$ & Lab experiments $\left(600 \mu \mathrm{g} \mathrm{C} 1^{-1}\right)$ & Stuart (1986) \\
E. lucens & $0.7-8.4 \%$ & $2.5-5.6 \%$ & In situ gut fluorescence & This study \\
\hline
\end{tabular}

Table 8. Euphausia lucens. Parameters of allometric equations

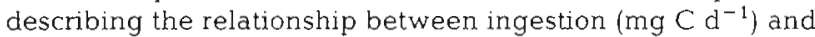
clearance $\left(\mathrm{ml} \mathrm{d}^{-1}\right)$ rates and body dry weight $(\mathrm{W}=\mathrm{mg} \mathrm{C})$. Rate $=\mathrm{aW}$

\begin{tabular}{lrcc|}
\hline Rate & $\mathrm{a}$ & $\mathrm{b}$ & $\mathrm{r}^{2}$ \\
\hline Ingestion & 20.99 & 0.86 & 0.82 \\
Filtration & 418.79 & 0.90 & 0.94 \\
\hline
\end{tabular}

0.91 obtained by Ross (1982) for all developmental stages of E. pacifica feeding on cultured diatom cells.

Carbon-specific ingestion rates when feeding on copepods were similar to those for phytoplankton, ranging from 2.17 to $4.83 \%$ body $\mathrm{C} \mathrm{d}^{-1}$ (Table 5). Between 11 and 26 copepods were ingested per day, depending on ambient phytoplankton concentrations, but due to smaller copepods being ingested in Cruise 2, the carbon-specific rations were lower than for Cruise 3. Adult Euphausia lucens thus appear to be true omnivores, obtaining ca $60 \%$ of their total carbon ration from phytoplankton sources when chlorophyll levels are relatively high (Table 6), whereas under conditions of very low chlorophyll levels (Cruise 2), camivory may provide up to $85 \%$ of total carbon ingested. Carnivory alone yields a maximum of $5.56 \%$ body $\mathrm{C} \mathrm{d}^{-1}$ as compared to $8.42 \%$ for phytoplankton. Minimum respiratory requirements for adult $E$. lucens of this size are ca $5.6 \%$ body $\mathrm{C} \mathrm{d}^{-1}$ (Stuart 1986). During conditions of high food availability (Cruise 3), this requirement could be fulfilled through the consumption of phytoplankton alone or copepods alone (Table 5). However, during periods of reduced food abundance, E. lucens must feed omnivorously to meet these requirements, and on Cruise 2 where very low phytoplankton concentrations prevailed, a mixed diet still failed to provide sufficient energy returns. Similarly, McClatchie (1985) found that Meganyctiphanes norvegica could only achieve its metabolic require- ments by feeding on high concentrations of natural copepod assemblages. Likewise, Price et al. (1988) demonstrated that in laboratory feeding experiments $E$. superba was able to obtain $83 \%$ of minimum respiratory requirements from copepods alone. However, at typical copepod concentrations reported for Antarctic waters, such feeding would meet less than $10 \%$ of their minimal metabolic requirements. Ohman (1984), on the other hand, found that E. pacifica could ingest only $0.45 \%$ of its body $\mathrm{C}^{-1}$ from copepods and $6.3 \%$ from diatoms at a similar food concentration. Prey concentrations used in this study were, however, relatively low, which may have depressed predation rates. Prey size and species may also affect predation rates, since different copepod species have been shown to have differential escape responses (Ohman 1988). The ability of $E$. lucens to feed omnivorously thus allows it to withstand periods of low phytoplankton concentrations which would otherwise result in conditions of near starvation for obligate herbivores.

\section{Grazing and predatory impact}

The grazing impact of Euphausia lucens on phytoplankton stocks in the southern Benguela region was estimated from the density of euphausids present on each cruise (no. $\mathrm{m}^{-3}$ ), their ingestion rates (Table 4 ) and the average chlorophyll concentrations in the upper $30 \mathrm{~m}$ of the water column. According to these calculations the total amount of pigment ingested per day by the entire $E$. lucens population represents only a very small fraction of the phytoplankton standing stocks in the upper $30 \mathrm{~m}$, ranging from 0.08 to $1.05 \%$ (Table 9). Copepods in this area also have a limited grazing impact on phytoplankton stocks, with estimates of 1 to $5 \%$ of the total available food being consumed by the entire copepod community (Peterson et al. 1990). The grazing activity of the entire mesozooplankton population will thus have little affect on the 
Table 9. Grazing impact of the Euphausia lucens population on phytoplankton standing stocks on each cruise

\begin{tabular}{|c|c|c|c|c|}
\hline & No. $\mathrm{m}^{-3}$ & $\begin{array}{c}\text { Ingestion } \\
\text { (ng pig. } \mathrm{m}^{-3} \mathrm{~d}^{-1} \text { ) }\end{array}$ & $\operatorname{Chl}\left(\mu \mathrm{g} \mathrm{l^{-1 }}\right)$ & $\%$ Chl ingested \\
\hline \multicolumn{5}{|l|}{ Cruise 1} \\
\hline Adults & 7.41 & 11855.06 & 1.14 & \\
\hline Juveniles & 2.56 & 358.63 & 1.14 & \\
\hline Furcilia & 11.27 & 277.08 & 1.14 & \\
\hline Calyptopis & 4.25 & 50.92 & 1.14 & \\
\hline Total ingestion & & 12541.69 & & $1.05 \%$ \\
\hline \multicolumn{5}{|l|}{ Cruise 2} \\
\hline Adults & 8.30 & 1698.26 & 0.64 & \\
\hline Juveniles & 9.72 & 732.99 & 0.64 & \\
\hline Furcilia & 1.30 & 20.28 & 0.64 & \\
\hline Calyptopis & 0.91 & 8.46 & 0.64 & \\
\hline Total ingestion & & 2459.99 & & $0.31 \%$ \\
\hline \multicolumn{5}{|l|}{ Cruise 3} \\
\hline Adults & 1.20 & 4478.05 & 4.96 & \\
\hline Juveniles & 0.49 & - & - & \\
\hline Furcilia & 2.82 & 112.84 & 4.96 & \\
\hline Calyptopis & 10.42 & 195.39 & 4.96 & \\
\hline Total ingestion & & 4818.98 & & $0.08 \%$ \\
\hline
\end{tabular}

dynamics of phytoplankton blooms in the southern Benguela upwelling region. This is consistent with the results of a carbon flow model of the Benguela upwelling area, which suggests that $75 \%$ of the primary production is lost as detritus annually (Berg et al. 1985). Also, Pitcher et al. (in press) concluded that natural mortality and breakdown of phytoplankton cells may be the most important factor accounting for the decline of phytoplankton blooms in the southern Benguela.

Euphausiids, however, may play a more important role in regulating zooplankton assemblages in the southern Benguela region. The potential predatory impact of adult euphausiids on copepod stocks was estimated in a similar fashion to their grazing impact. Assuming an average ingestion rate of 17.6 copepods adult ${ }^{-1} \mathrm{~d}^{-1}$ (mean of values presented in Table 5) and a maximum population abundance of 8.3 adults $\mathrm{m}^{-3}$ (Table 9), this population would consume 146 copepods $\mathrm{m}^{-3} \mathrm{~d}^{-1}$. Copepod densities in this area are variable, ranging from 2000 to $6000 \mathrm{~m}^{-3}$ (Verheye 1990). At the above predation rates, Euphausia lucens adults would consume 2.4 to $7.3 \%$ of the copepod population per day. However, since the Bongo net integrates plankton throughout the water column, the density of euphausiids is likely to be underestimated due to their frequent swarming behaviour. Densities of up to 68 adults $\mathrm{m}^{-3}$ have been recorded for the St Helena Bay area from monthly samples collected over 1 yr (Pillar \& Stuart 1988) and, under these conditions, E. lucens could exert a considerable predatory impact on the copepod standing stocks, consuming up to $60 \%$ of the population per day. It should be borne in mind, though, that copepod densities are equally variable and patchy and such predation rates are likely to occur infrequently.

Predation within the zooplankton community, such as observed in this study, may be responsible for the observation that the Benguela upwelling system supports a much lower zooplankton biomass than would have been predicted from its high primary production (Borchers \& Hutchings 1986). Predation by copepods, chaetognaths and euphausiids combined with the heavy predation pressure from many of the pelagic fish species such as anchovy and sardine (James 1987) may all be contributing factors for this relatively low zooplankton biomass.

Acknowledgements. We thank Drs W.T Peterson, M. Gibbons and L. Hutchings for constructive comments on the manuscript, as well as Isolda Rojas and Jillian Burbidge for technical assistance. This study was funded by a research grant from the South African National Committee for Oceanographic Research (SANCOR), for the Benguela Ecology Program. We also thank the Director of the Sea Fisheries Research Institute, South Africa, for funds and facilities to do this work.

\section{LITERATURE CITED}

Antezana, T., Ray, K. (1984). Active feeding of Euphausia superba in a swarm north of Elephant Island. J. Crust. Biol. 4 (Spec. no. 1): 142-155

Berg, M. O., Field, J. C., Shannon, L. V. (1985). A preliminary carbon budget of the southern Benguela pelagic ecosystem. In: Bas, C., Margalef, R., Rubies, P. (eds.) International symposium on the most important upwelling areas off western Africa (Cape Blanco and Benguela), Vol. 1. 
Instituto de investigaciones Pesqueras, Barcelona, p. 281-304

Borchers, P. Hutchings, L. (1986). Starvation tolerance, developmental time and egg production of Calanoides carinatus in the southern Benguela current. J. Plankton Res. 8: 855-874

Brown, P. C. (1984). Primary production at two contrasting nearshore sites in the southern Benguela upwelling region, 1977-1979. S. Afr. J. mar Sci. 2: 205-215

Brown, P. C., Hutchings, L. (1987). The development and decline of phytoplankton blooms in the southern Benguela upwelling system. 1. Drogue movements, hydrography and bloom development. S. Afr. J. mar. Sci. 5: 357-391

Conover, R. J., Durvasula, R., Roy, S., Wang, R. (1986). Probable loss of chlorophyl-derived pigments during the passage through the gut of zooplankton, and some of the consequences. Limnol. Oceanogr. 31.878-887

Daan, R., Gonzalez, S. R., Klein Breteler, W C. M. (1988) Cannibalism in omnivorous calanoid copepods. Mar. Ecol. Prog. Ser. 47: 45-54

Dagg, M. J., Walser, W. E. (1987). Ingestion, gut passage and egestion by the copepod Neocalanus plumchrus in the laboratory and in the subarctic Pacific ocean. Limnol. Oceanogr. 32: 178-188

Dagg, M. J., Wyman, K. D. (1983). Natural ingestion rates of the copepods Neocalanus plumchrus and $N$. cristatus calculated from gut contents. Mar. Ecol. Prog. Ser 13: 37-46

Dam, H., Peterson, W. T (1988). The effect of temperature on the gut clearance rate of planktonic copepods. J. exp. mar. Biol. Ecol. 123: 1-14

Hayward, T. C. (1980). Spatial and temporal feeding patterns of copepods from the North Pacific Central Gyre. Mar. Biol. 58: 295-309

Head, E. J. H. (1988). Copepod feeding behaviour and the measurement of grazing rates in vivo and in vitro. Hydrobiologia 167/168: 31-41

Head, E. J. H., Harris, L. R., Abou Debs, C. (1985). Effect of daylength and food concentration on in situ diurnal feeding rhythms in arctic copepods. Mar. Ecol. Prog. Ser. 24: $281-288$

Head, E. J. H., Wang, R., Conover, R. J. (1984). Comparison of diumal feeding rhythms in Temora longicornis and Centropages hamatus with digestive enzyme activity. J. Plankton Res. 6: 543-551

Hu, V J. H. (1978). Relationship between vertical migration and diet in four species of euphausiids. Limnol. Oceanogr. 23: 296-306

Huntley, M. E., Marin, V., Escritor, F. (1987). Zooplankton grazers as transformers of ocean optics: a dynamic model. J. mar. Res. 45: 911-945

Isaacs, J. D. (1972). Unstructured marine food webs and pollutant analogues. Fish. Bull. U.S. 70: 1053-1059

Isaacs, J. D. (1977). The life of the open sea. Nature, Lond. 267: $778-780$

James, A. G. (1987). Feeding ecology, diet and field-based studies on teeding selectivity of the cape anchovy Engraulis capensis Gilchrist. S. Afr. J. mar. Sci. 5: 673-692

Kiorboe, T B., Mohlenberg, F., Nicolajsen, H. (1982). Ingestion rate and gut clearance in the planktonic copepod Centropages hamatus (Lilljeborg) in relation to food concentration and temperature. Ophelia 21. 181-194

Landry, M. R. (1981). Switching between herbivory and carnivory by the planktonic marine copepod Calanus pacificus. Mar Biol. 65: 77-82

Lopez, M. D. G., Huntley, M. E., Sykes, P. F. (1988). Pigment destruction by Calanus pacificus: impact on the estimation of water column fluxes. J. Plankton Res. 10: 715-734
Mackas, D., Bohrer, R. (1976). Fluorescence analysis of zooplankton gut contents and an investigation of diel feeding patterns. J. exp. mar. Biol. Ecol. 25: 77-85

Marschall, H. P. (1985). Structural and functional analyses of the feeding appendages of krill larvae. In: Siegfried. W. R., Condy, P. R., Laws, R. M. (eds.) Antarctic nutrient cycles and food webs. Springer-Verlag. Berlin, p. 346-354

Mauchline, J. (1966). The biology of Thysanoessa raschii (M. Sars) with a comparison of its diet with that of Meganyctiphanes norvegica (M. Sars). In: Barnes, H. (ed.) Some contemporary studies in marine science. Allen and Unwin, London, p. 493-510

McClatchie, S. (1985). Feeding behaviour in Meganyctiphanes norvegica (M. Sars) (Crustacea: Euphausiacea). J. exp. mar. Biol. Ecol. 86: 271-284

Morris, D. J. (1984). Filtration rates of Euphausia superba DANA: under- or overestimates. J. Crust. Biol. 4 (Spec. no. 1): $185-197$

Ohman, M. D. (1984). Omnivory by Euphausia pacifica: the role of copopod prey. Mar. Ecol. Prog. Ser. 19: 125-131

Ohman, M. D. (1988). Behavioural responses of zooplankton to predation. Bull. mar. Sci. 43: 530-550

Paffenhöfer, G. A. (1988). Feeding rates and behaviour of zooplankton. Bull. mar. Sci. 43: 430-445

Parsons, T., LeBrasseur, R. J., Fulton, J. D. (1967). Some observations of the dependence of zooplankton grazing on the cell size and concentration of phytoplankton blooms. J. Oceanogr. Soc. Jap. 23: 10-17

Payne, A. I. L., Rose, B., Leslie, R. W. (1987). Feeding of hake and a first attempt at determining their trophic role in the south African west coast marine environment. S. Afr J. mar. Sci. 5: 471-501

Peterson, W T., Painting. S. J., Hutchings, L. (1990). Diel variations in gut pigment content, diel vertical migration and estimates of grazing impact for copepods in the southern Benguela upwelling region, in October, 1987. J. Plankton Res. 12: 259-281

Pillar, S. C. (1984a). Laboratory studies on the larval growth and development of Euphausia lucens (Euphausiacea). S. Afr J. mar. Sci. 2: 43-48 (1984)

Pillar, S. C. (1984b). A comparison of the performance of four zooplankton samplers. S. Afr. J. mar. Sci. 2: 1-18

Pillar, S. C., Armstrong, D. A., Hutchings, L. (1989). Vertical migration, dispersal and transport of Euphausia lucens in the southern Benguela current. Mar. Ecol. Prog. Ser. 53: $179-190$

Pillar, S. C., Stuart, V. (1988). Population structure, reproductive biology and maintenance of Euphausia lucens in the southern Benguela current. J. Plankton Res, 10: 1083-1098

Pitcher, G. C., Walker, D. R., Mitchell-Innes, B. A., Moloney, C. L. (in press). Short-term variability during an anchor station study in the southern Benguela upwelling system: phytoplankton dynamics. Prog. Oceanogr

Price, H. J., Boyd, K. R., Boyd, C. M. (1988). Omnivorous feeding behaviour of the Antarctic krill Euphausia superba. Mar. Biol. 97. 67-77

Ross, R. M. (1979). Carbon and nitrogen budgets over the life of Euphausia pacifica. Ph.D thesis, Univ, of Washington

Ross, R. M. (1982). Energetics of Euphausia pacificd. I. Effects of body carbon and nitrogen and temperature on measured and predicted production. Mar. Biol. 68: 1-13

Sameoto, D. D. (1981). Relationship between stomach content and vertical migration in Meganyctiphanes norvegica Thysanoessa raschii and T. inermis (Crustacea Euphausiacea). J. Plankton Res. 2: 129-143

Simmard, Y., Lacroix, G., Legendre, L. (1986). Diel vertical migrations and nocturnal feeding of a dense coastal krill 
scattering layer (Thysanoessa raschii and Meganyctiphanes norvegica) in stratified surface waters. Mar. Biol. 91 93-105

Stuart, V (1986). Feeding and metabolism of Euphausia lucens (Euphausiacea) in the southern Benguela current. Mar Ecol. Prog. Ser. 30: 117-125

Stulart, V (1989). Observations on the feeding of Euphausia lucens on natural phytoplankton suspensions in the southern Benquela upwelling region. Cont. Shelf Res. 9: $1017-1028$

Stuart, V., Pillar, S. C. (1988). Growth and production of Euphausia lucens in the southern Benguela current. J. Plankton Res. 10: 1099-1112

Sullivan, B. K. Peterson, W T., Soeldner, A. H. (1975). A scanning electron microscope study of the mandibular morphology of boreal copepods. Mar. Biol. 30: 175-182

Turner, J. T (1984). Zooplankton feeding ecology: contents of faecal pellets of the copepods Eucalanus pileatus and

This article was submitted to the editor
Paracalanus quasimodo from continental shelf water of the Gulf of Mexico. Mar Ecol. Prog. Ser 15: 27.46

Verheye, H. M (1990). Distribution, dynamics and production of the copepod Calanoides carinatus (Kroyer, 1849) in the southern Benguela upwelling region. Ph.D. thesis, Univ. of Cape Town

Vidal, J. (1980). Physioecology of zooplankton. 1 Effects of phytoplankton concentration, temperature and body size on the growth rate of Calanus pacificus and Pseudocalanus sp. Mar Biol. 56: 111-134

Wang, R., Conover, R. J. (1986). Dynamics of gut pigment in the copepod Temora longicornis and the determination of in situ grazing rates. Limnol. Oceanogr. 31: 867-877

Willason, S. W., Cox, J. L. (1987). Diel feeding, laminarinase activity and phytoplankton consumption by euphausiids. Biol. Oceanogr. 4: 1-24

Zar, J. H. (1984). Biostatistical analysis. Prentice-Hall, Englewood Cliffs, New Jersey

Manuscript first received: January 11, 1990

Revised version accepted April 26, 1990 